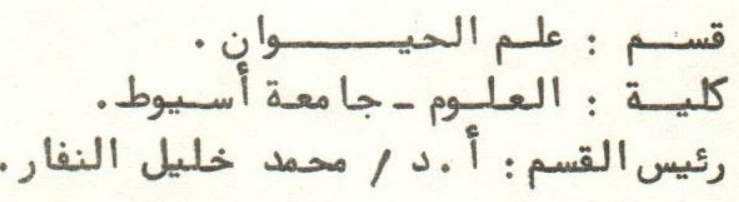

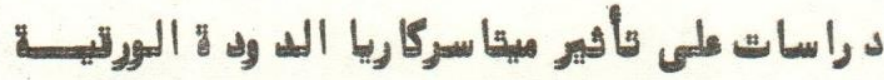

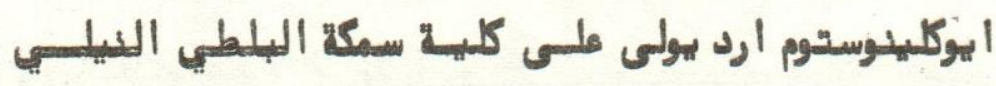

$$
\text { عـزت يواقسيم ، محمد النفار }
$$

يتضمن هذا البحث د راسات هستولوجية وهستوبا ثولوجية وهستوكيميا ئية على الى الئي

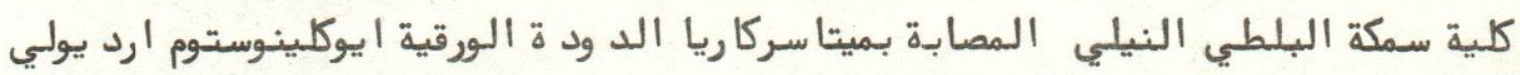

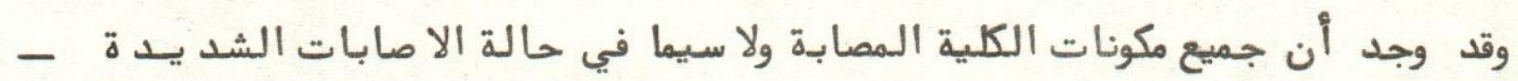

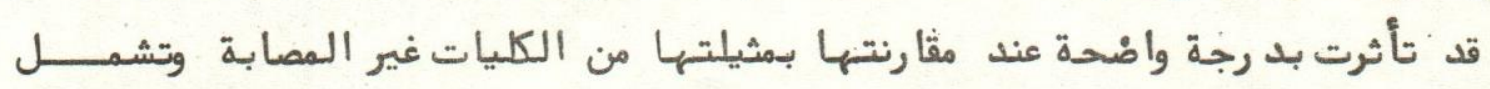

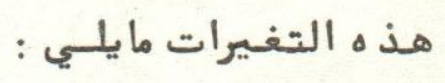

ـ ـ احتقان الجُمّع وتهتكه في بعض الاحيان وتمزق محفظة بومـان .

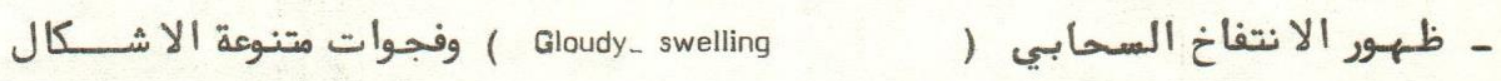
وتهتك الاطراف الحسرة لمعظم خلايا الإنيا الانييوبات.

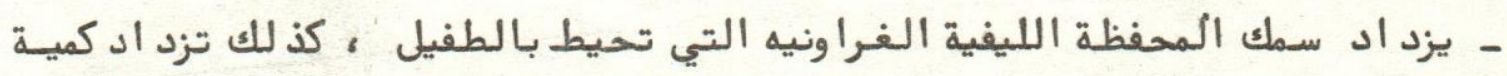
النسيج الضام بين الانيبويات بزيادة شدة الاصابة .

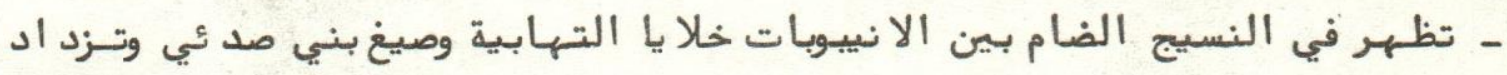

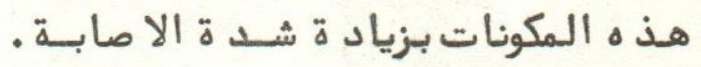

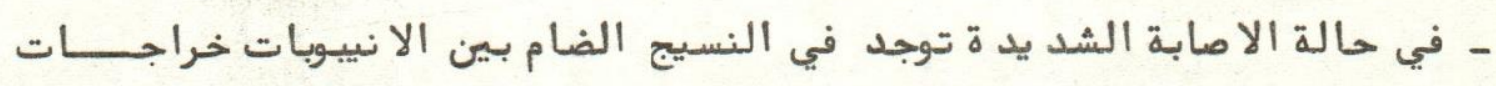
محاطة بخلا يا التهابيه وكرات د مويـه حمـراء .

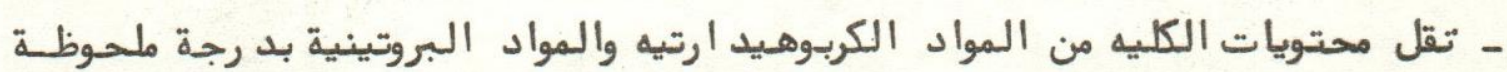
بينما يكون الطفيل غنيا بهذه المكونسات. 

Dept. of Zoology,

Faculty of Science, Assiut University,

Head of Dept. Prof. Dr. M.K. El-Naffar.

\title{
STUDIES ON THE EFFECTS OF METACERCARIA OF THE PARASITIC TREMATODE EUCLINOSTOMUM ARDEOLAE ON THE KIDNEYS OF THE NILE CICHLID FISH TILAPIA NILOTICA \\ (With 4 Plates)
}

\author{
By \\ E.G. YOAKIM and M.K. El-NAFFAR \\ (Received at 22/5/1985)
}

\begin{abstract}
SUMMARY
This investigation is mainly concerned with the histopathological effects of the metacercaria of the parastiic trematode Euclinostomum ardeolae (EL-NAFFAR and KHALIFA, in press) on the kidney of the Nile cichlid fish Tilapia nilotica. Fifteen fishes, including normal, slightly infected and haevily infected ones were investigated. The glomeruli, proximal and distal convoluted tubules, collecting tubules and intertubular connective tissue displayed clear signs of degeneration, the extent of which depends on the intensity of infection.
\end{abstract}

\section{INTRODUCTION}

Studies on the histopathological effects of the parasitic adult and larval stages of trematodes on the kidneys of submammalian vertebrates are rather scanty. Only few reports are available in this connection including those of TIMON-DAVID (1933 and 1952), WRIGHT (1956), RILEY and OWEN (1972) and EL-NAFFAR et al. (1977).

RECENTLY, EL-NAFFAR and KHALIFA (in press) reported that the metacercariae of the trematode parasitc Euclinostomum ardeolae sp. nov. were found to be encysted in the kidnys of the Nile cichlid fish, Tilapia nilotica. A maximum of five metacercariae per one kidney has been recorded. In the present investigation it is intended to give an account on the histopathological effects of the aforementioned metacercaria on the kidneys of Tilapia nilotica which is one of the most important economic fish species of the Nile.

\section{MATERIALS and METHODS}

Live speccimens of Tilapia nilotica were collected from the Nile River at Assiut governorate during the period March to June, 1977. The kidneys were dissected out in physiological saline solution and the number of metacercariae, if present, was recorded for each infected fish. The latter were classified into two categories according to the number of metacercariae encountered in their kidneys : slight $(1-2$ metacercariae) and heavy (35 metacercariae). The kidneys of five specimess of each category and those of five normal specimens were cut into represrntative pieces and fixed in Bouin's Zenker's formal, Carnoy's

Assiut Vet. Med. J. Vol. 15, No. 30, 1986. 


\section{YOAKIM \& EL-NAFFAR}

or acetic acid formalin fluids. Paraffin sections, $5-7 \mu$ thick, were cut and stained in either Harris's haematoxylin and eosin or Mallary's tripple stains.

PAS technique (McMANUS, 1948) was used for the demonstration of $1: 2$ glycol linkage of carbohydrates. Control slides were incubated in saliva at $37^{\circ} \mathrm{C}$ for one hour prior to PAS staining. Best's carmine was used for the detection of glycogen; control slides were treated in the same way as those in the PAS technique. Mercury bromophenol blue as recommended by MAZIA, BREWER and ALFERT (Pearse, 1960) was used for the detection of proteins.

\section{RESULTS}

\section{Normal kidney}

The kidney of Tilapia nilotica has no zones of cortex and medulla as in mammals. Rather it consists of renal units in no specific pattern. Each renal unit is composed of a glomerulus and a uriniferous tubule which is differentiated into the neck segment, proximal convoluted tubule and the distal convoluted tubule. The latter is connected with the collecting tubule. The intertubular connective tissue contains blood vessels and few collagenous fibres.

The glomerulus is well developed; it is made up of Bowman's capsule embracing a tuft of capillaries. The simple squamous cells of the Bowman's capsule blend directly with the low cuboidal cells lining the neck segment (Fig. 1). The proximal convoluted tubule is differentiated histologically into two segments. The first segment, which is of a larger diameter than the second, is composed of columnar cells the cytoplasm of which stains lightly with eosin and their oval nuclei are basally located. The second segment is formed of cuboidal cells having their cytoplasm more eosinophilic than that of the first segment and their nuclei are centrally located. The distal convoluted tubule is made up of high columnar cells which have faintly stained eosinophilic cytoplasm and oval basal nuclei (Fig. 2). The collecting tubule is lined by pseudostratified epithelium and it is surrounded by a rather thick layer of collagenous fibres (Fig. 3).

Histochemically, the glomerular tuft reveals a faint PAS - positive reaction, whereas the brush border of the proximal convoluted tubule shows a conspicuous PAS - positive reaction. No change in the intensity of PAS reaction has been revealed by control sections. Moreover, Best's cormine gives a negative reaction. These results indicate the presence of carbohydrate material other than glycogen.

All the components of the renal units react positively towards mercury bromophenol blue, indicating their protein content; however, the first segment of the proximal convoluted tubule is less stainable (Fig. 5).

\section{2- The infected kidney}

In slightly infected kidneys, the parasite is surrounded by a capsule of collagenous fibres, the average thickness of which is $36 \mu$ (Fig. 6). Some glomeruli show signs of congestion; the glomerular tufts are dilated and reveal a large number of red blood corpuscles as compared with the normals. However, the Bowman's capsules are intact (Fig. 7). 
The cells of most proximal convoluted tubules, distal convoluted tubules and collecting tubules reveal sings of cloudy swelling. Thus, the cells are enlarged, the cytoplasm is granular and the nuclei are swollen and have few chromatin granules. The enlargement of the cells lining the proximal convoluted tubules usually results in a marked reduction or even obliteration of their lumina (Fig. 7).

As compared with the normal kidney, the intertubular connective tissue of the slightly infected kidney slightly increases and is infiltered, especially near the fibrous capsule surrounding the parsite, by extravasated red blood corpuscles and inflammatory cells. The latter included granular leucocytes, lymphocytes and macrophages. Clusters of rusty brown particles are occasionally encountered in the intertubular connective tissue or intermingled with the collagenous fibres surrounding the collecting tubules. Such rusty brown particles are sometimes seen in the cytoplasm of macrophages (Figs. 7, 8 a \& b).

In the heavily infected kidneys, the fibrous capsule surrounding the parsite increases markedly in thickness which measures on the average $61 \mathrm{u}$. Congested glomeruli, as described in the slightly infected kidneys, are of frequent occurrence. Many glomeruli have ruptured Bowman's capsules and glomerular tufts (Fig. 9). Some glomeruli are greatly affected, thus their glomerular tufts shrink forming structurless deeply eosinophilic masses (Fig. 10).

Few proximal and distal convoluted tubules show hydropic degeneration; the cells are swollen and have faintly stained vacuolated cytoplasm and pyknotic nuclei. The cells of most proximal and distal convoluted tubules have highly vacuolated cytoplasm, ruptured luminal ends and pyknotic nuclei (Fig. 11). Occasionally, the cells of the proximal and distal convoluted tubules are totally detached from the basement membrane forming groups of scattered cells, or they may collapse to form compact masses of cells with pyknotic nuclei (Fig. 12). The aforementioned histopathological changes are also revealed by the collecting tubules (Figs. 13 a \& b).

The intertubular connective tissue of the heavily infected kidney, as compared with that of the normal one, is markedly increased. Such a tissue reveals the presence of inflammatory cells, extravasated red blood corpuscles, clusters of brown particles similar to those described in that of the slightly infected kidney but in a more pronounced manner (Fig. 14). Moreover, the intertubular connective tissue contains several abscesses. Each absecess is formed of a cavity surrounded by numerous inflammatory cells and 'extravasated red blood corpuscles (Fig. 15).

As compared with the normal kidney, both the slightly and haevily infected kidneys have many of their glomerular tufts intensely stained with PAS reaction, whereas, the brush border of the proximal convoluted tubules is negatively stained with that reaction (Fig. 16). Best's carmine reveals the presence of glycogen in the intercellular substance of the parenchymatous tissue of the parasite and its absence in the renal tissue (Fig. 17). Mercury bromophenol blue shows that the protein content of the tubules is greatly diminished; however, the parasite is rich in protein (Fig. 18).

\section{DISCUSSION}

The kidney of Tilapia nilotica has been found to contain well developed vascularized glomeruli. This agrees with the generalization postulated by SOMAYAJULU and KAMAT (1972) that the glomeruli are well developed in fresh water fishes as there is a need for the elimination of water, whereas they are illdeveloped in marine fishes as there is a necessity for retention of water.

Assiut Vet. Med. J. Vol. 15, No. 30, 1986. 


\section{YOKIM \& E-NAFFAR}

In Tilapia nilotica the uriniferous tubule is differentiated into, neck segment, proximal convoluted tubule and distal convoluted tubule. The neck segment lacks çilia; in this respect it resembles of that Xiphophorus helleri but differs from that of Danio malabaricus (EDWARDS, 1935). As in Ictalurus punctatus (KENDALL and HINTON, 1974), the proximal convoluted tubule in Tilapia nilotica is differentiated into two segments.

- To the best of our knowledge, the histopathological effects of trematodes on the kidneys of fishes are lacking. Only few reports on the histopathologic effects of trematode parasites belonging to the genus Renicola on the kidneys of some birds are available. TIMON - DAVID (1933) stated that the kidneys of Larus argentatus infected with Renicola lari showed little or no host tissue reaction. Conspicuous renal leșions were reported by TIMON - DAVID (1952) in Pica pica infected with Renicola bretensis. WRIGHT (1956), noticed a complete lack of host tissue reaction in the kidneys of Puffinus puffinus infected with unnamed species of Renicola. RILEY \& OWEN (1972) came to the conclusion that recently established Renicola glacialis in the kidneys of Fulmarus glacialis elisted only a slight host. tissue response, but older infections were accompanied by pronounced eosinophilia and a thick connective tissue sheath investing the parasite. EL-NAFFAR et al. (1977) reported that the effects of Renicola ardeolae on the kidney tubules of the buff - backed heron, Ardeolae ibis include cloudy swelling, pyknosis of nuclei and necrosis.

Results of the present investigation have revealed that the metacercaria of the parasitic trematode, Euclinostomum ardeolae markely affected the histological studcture of the kidney of Tilapia nilitica, especially in the heavily infected specimens. The host surrounded the parasite by a capsule of collagenous fibres, the thickness of which was considerably increased in heavily infected specimens. The glomeruli were found to be either congested, ruptured or with shrunken deeply eosinophilic glomerular tufts. The cells of the kidney tubules showed signs of degeneration, high vacuolation of cytoplasm, phknosis of nuclei and detachment from the basement membrane forming scattered groups or compact masses of cells. In heavily infected kdneys, the intertubular connective tissue was markedly increased and revealed the presence of inflammatory cells, extravasated red blood corpuscles, clusters of rusty brown particles and abscesses. The presence of extravasated red blood corpuscles were due to lesions in the blood vesels. The rusty brown particles were mostly haemosiderin resulting from distructuion of haemoglobin of the red blood corpuscles. This was more justified by the fact that such particles were frequently seen phagocytosed by the macrophages.

As compared with the normal kidney, the tubules of the infected kidney showed a marked decrese in proteins and carbohydrates other than glycogen. On the other hand, the tissues of he parasite were found to be rich in proteins and carbohydrates including glycogen. These results indicate that the parasite has got ample supply of these vital compounds at the expense of the host.

\section{REFERENCES}

Edwards, J.G. (1935): The epithelium of the renal tubule of bony fish. Anat. Rec., 63: 263 - 279.

El-Naffar, M.K.; Anwar, I.M. and Khalifa, R. (1977): Studies on the hiștopathology of Renicola ardeolae sp. nov. (Trematoda : Renicolinae). J. Egypt Soc. Parasit., $7 \frac{\text { (1): } \cdot 35}{-44 .}$ $-44$.

El-Naffar, M.K. and Khalifa, R. (in press): Euclinostomum ardeolae sp. nov. (Trematoda : Clinostomatidae) with the description of its life cycle. lbid. (in press). 
EFFECT OF METACERCARIA ON THE KIDNEY OF TRAPIA NLOTICA

Kendall,M.W. and Hinton,D.E. (1974): Renal tubular morphology in the channel catfish, Ictalurus punctatus kidney. J. Fish. Res. Board Can., 31 (3): 346 - 347.

McManus, J.F.A. (1948): Histological and histochemical uses of periodic acid. Stain Technol., 23: 99 - 108.

Pearse, A. (1960): Histochemistry, Theoretical and Applied. Churchill, London.

Riley, J. and Owen, R.W. (1972): Renicola glacialis sp. nov., a nwe termatode from the north sea Fulmar, Fulmaris glacialis (L.), with observations on its pathology. J. Helmenth., XLVI: $63-72$ :

Somayajulu, R.S.N. and Kamat, D.N. (1972): Comparative histology of the kidney of fishes from diverse habitats. J. Anat. Soc. India, 21 (3): 113 - 116.

Timon-David, J. (1933): Sur une nouvelle espece de Renicola trematode parasite du rein des

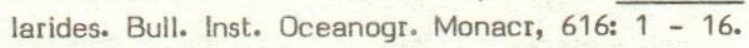

-1952): Une Renicola nouveau chez la pie. bull. Soc. Zool. Fr., 77 : 504 511.

Wright, C.A. (1956): Studies on the life history and ecology of the trematode genus Renicola Cohn 1904. Proc. Zool. Lond., 126: 1 - 48.

\section{LEGENDS}

Plate I :

Fig (1): T.S. of the normal kidney of T-nilotica, showing the structure of the glomerulus ar」 the neck segment. $\times 475$.

Fig. (2): T.S. of the normal kidney of T.nilatica, showing the structure of the proximal and distal convoluted tubules. $\times 230$.

Fig. (3): T.S. of the normal kidney of T.nilotica, showing the structure of the collecting tubule. $\times 475$.

Fig. (4): T.S. of the normal kidney of T.nilotica, showing the reaction of the constituents of the renal units towards the PAS reaction. X 120 .

Fig. (5): T.S. of the normal kidney of T.nilotica, showing the reaction of the constituents of the renal units towards mercury bromophenol blue. X 190.

Plate II :

Fig. (6): T.S. of the slightly infected kidney of T.nilotica showing the parasite surrounded by a collagenous connective tissue capsule. $\times 43$.

Fig. (7): T.S. of the slightly infected kidny of T.nilotica, showing congested glomeruli and cloudy swelling of the kidney tubules. $X 175$.

Fig. ( 8 a): T.S. of the slightly infected hidney of T.nilotica showing the intertubular connective tissue infiltered by extravasated red blood corpuscles, inflammatory cells and clusters of rusty hrown particles. X 425 .

Fig. ( $(\mathbf{B}$ b): T. S. of the slightry infected kidney of T.nilotica showing rusty brown particles phagocytosed by the macrobhages. $\times 450$.

Assiut Vet. Med. J. Vol. 15, No. 30, 1986. 


\section{Plate III :}

Fig. (9): T.S. of the heavily infected kidney of T.nilotica, showing glomeruli with ruptured Bowman's capsule and glomerular tufts. $\times 380$.

Fig. (10): T.S. of the heavily infected kidney of T.nilotica, showing a shrunken deeply eosinophilic glomerular tuft. $\times 380$.

Fig. (11): T.S. of the heavily infected kidney of T.nilotica, showing hydropic degeneration, high vacuolation of the cytoplasm, pyknotic nuclei and ruptured luminal ends of the proximal and distal convoluted tubular cells. $\times 380$.

Fig. (12): T.S. of the heavily infected kidney of T.nilotica, showing the proximal and distal convoluted cells are totally detached from the basement membrane forming groups of scatteled cells. Some such tubules collapse to form compact masses of cells with pyknotic nuclei. X 380 .

Fig. (13 a \& b): Transverse sections of the heavily infected kidney of T.nilotica, showing the histopathological effects revealed by the collecting tubule. $\times 230$ and 190 respectively.

Fig. (14): T.S. of the heavily infected kidney of T.nilotica, showing the marked increase of the intertubular cennective tissue and its infiltration with extravasated red blod corpuscles, inflammatory cells and rusty rown particles. X 152 .

Fig. (15): T.S. of the heavily infected kidney of T.nilotica, showing an obscess surrounded by inflammatory cells and red blood corpuscles. $\times 380$.

\section{Plate IV :}

Fig. (16): T.S. of the slightly infected kidney of T.nilotica, showing the reaction of the glomeruli and proximal convoluted tubules towords the PAS reaction. $\times 380$.

Fig. (17): T.S. of the slightly infected kidney of T.nilotica, showing the reaction of the parasite and the renal tissue towards Best's carmine. X 152 .

Fig. (18): T.S. of the slightly infected kidney of T.nilotica, showing the reaction of the parasite and the kidney tubules towards bromophenol blue. $\times 95$. 


\section{PLATE I}

14.

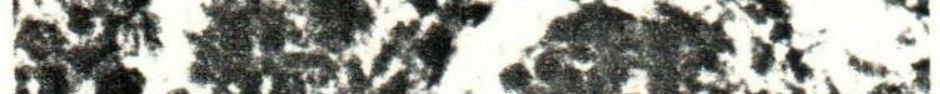
4200154 - 014 you $5-2 x^{5} 40$ $1.20 \%$

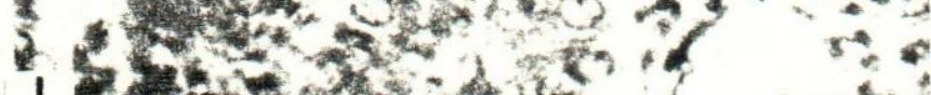

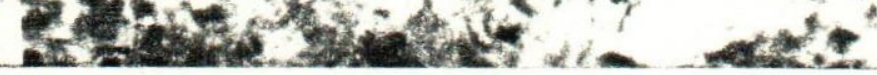

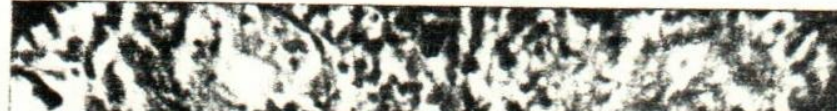
$306 x+2$ 2. 1 .

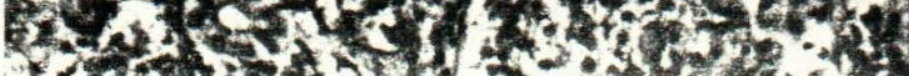
3140,50 135 , the Fen 140

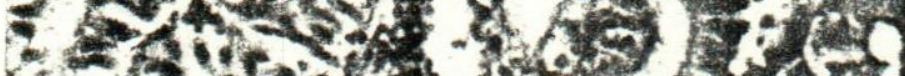
6. 70 . 40.6 , r

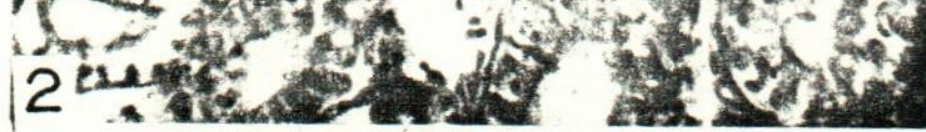
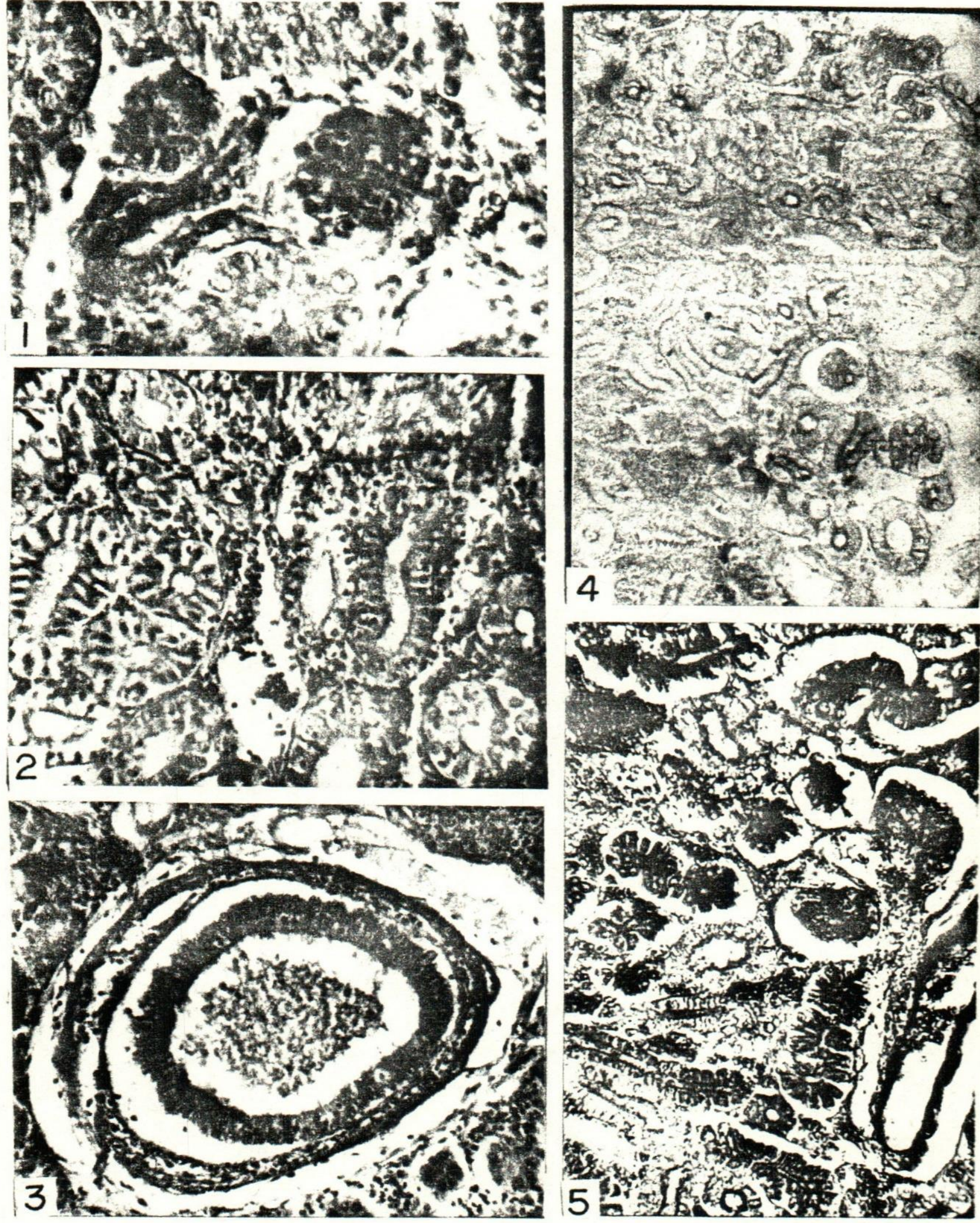

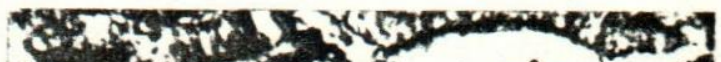

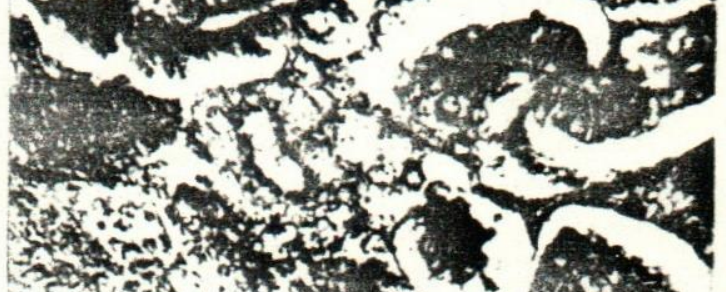
8 on

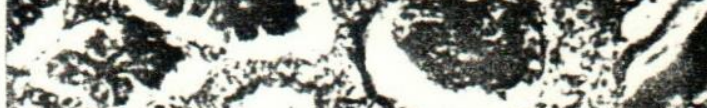

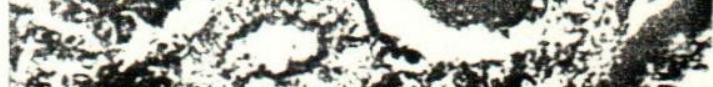
5.

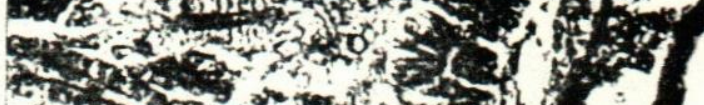
3. 

PLATE II

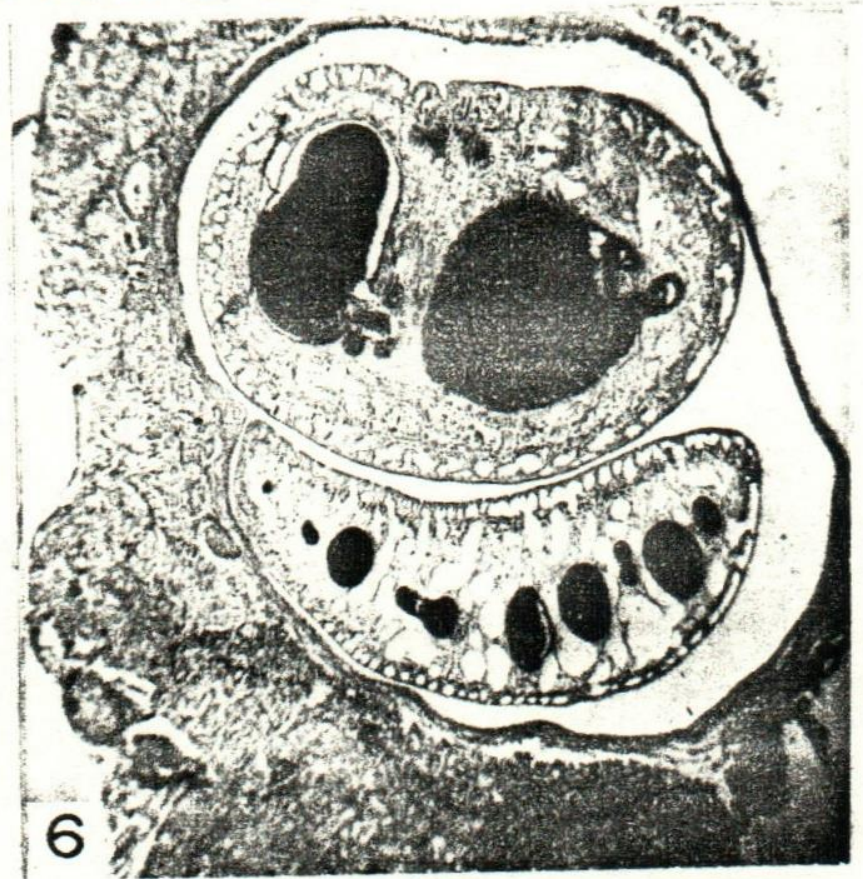

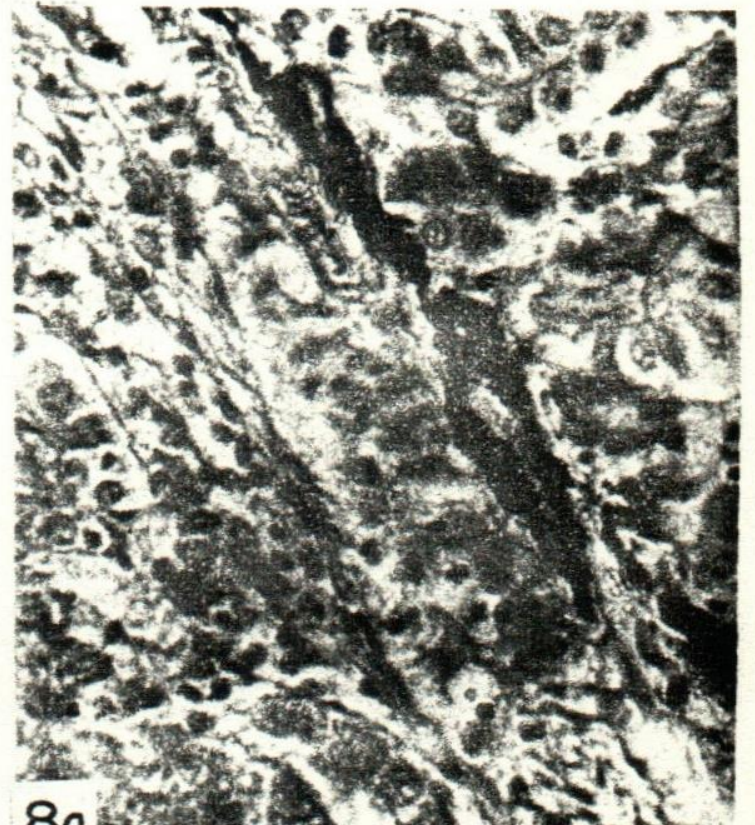
80.

my

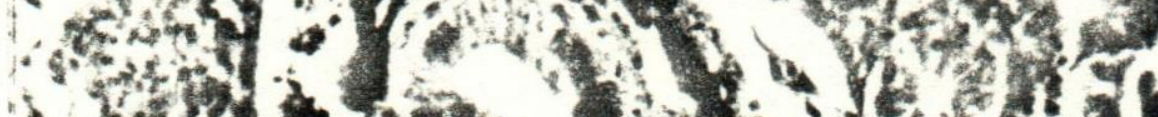
won 1,1

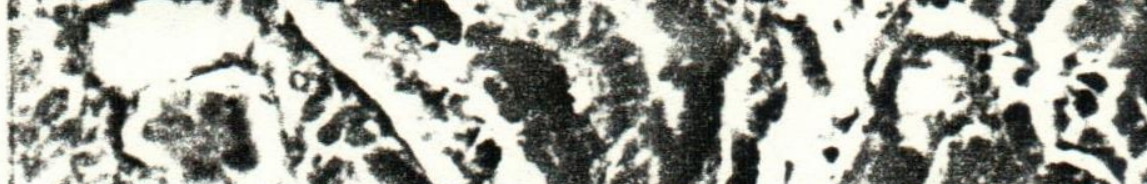

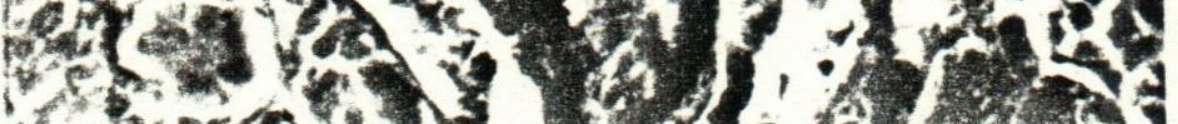
. 17\% 13. (5) $3 x$,

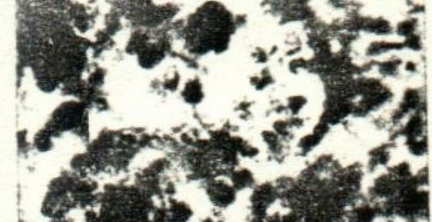
$3.4+2+1$
$8 b$ a 
$\checkmark$

$\bullet$ ,

เ

เ

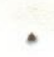
$\checkmark$ 
'PLATE III

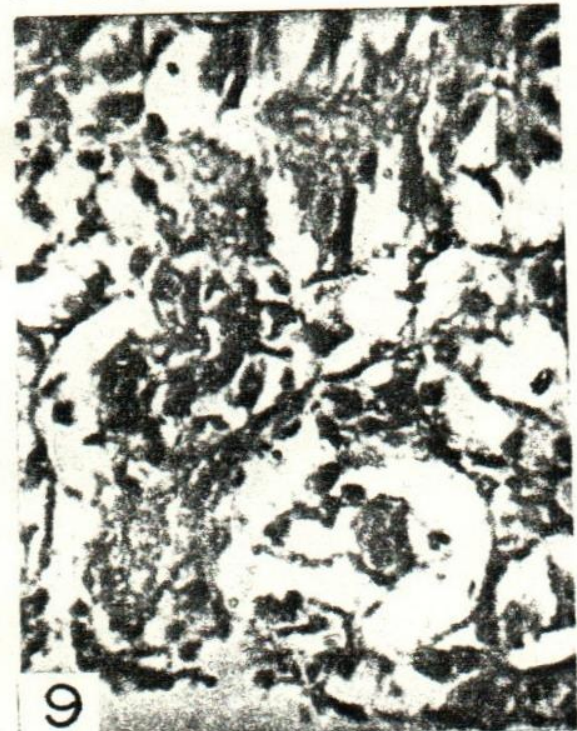

6.7\%

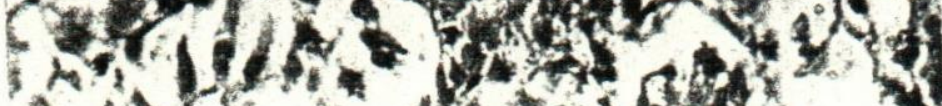
1,1 , do

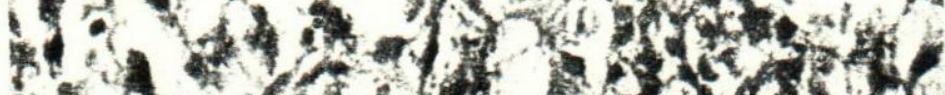
s. 2 Thente

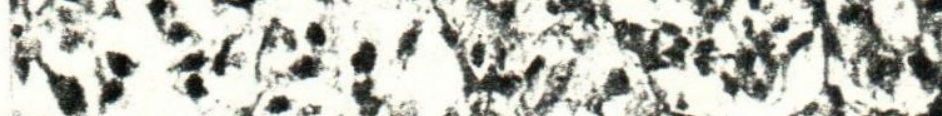

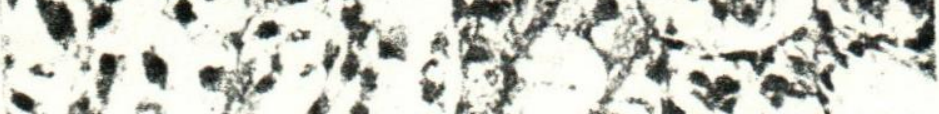

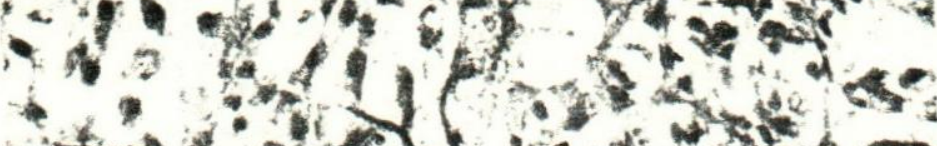

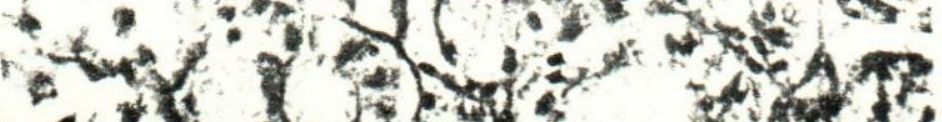
- v logl.

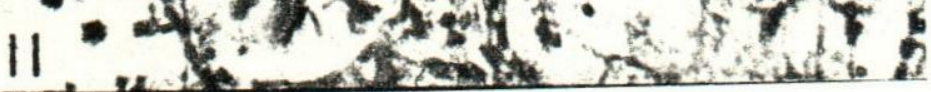

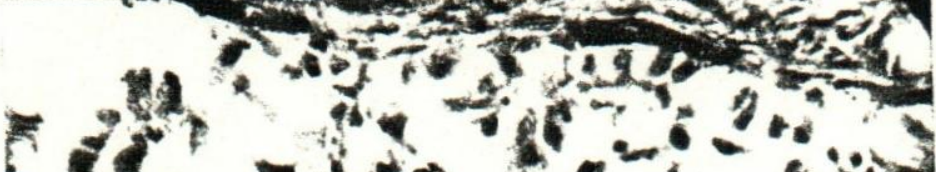

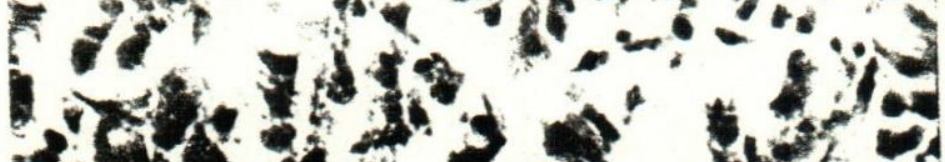

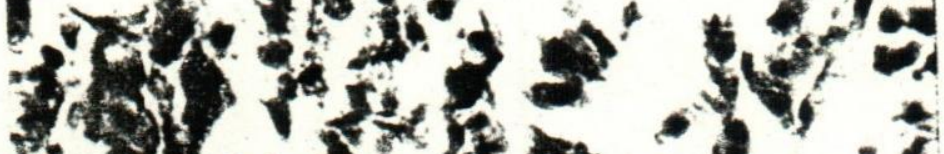

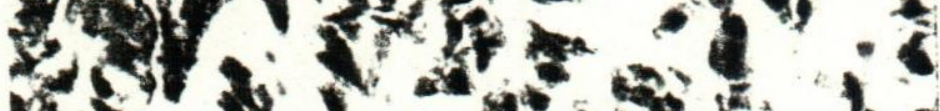

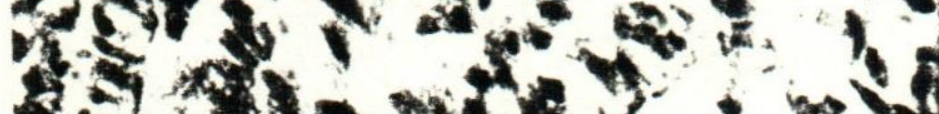

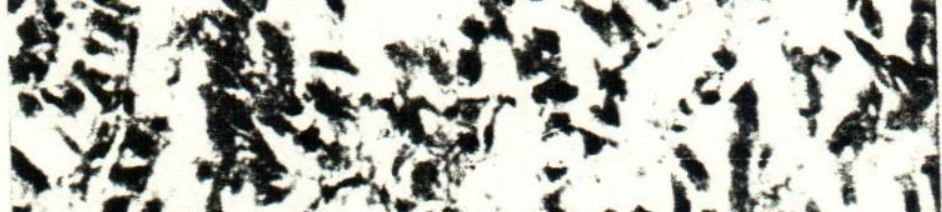

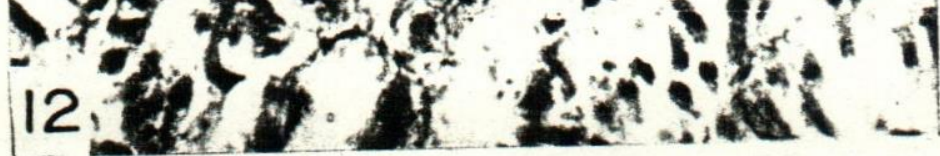

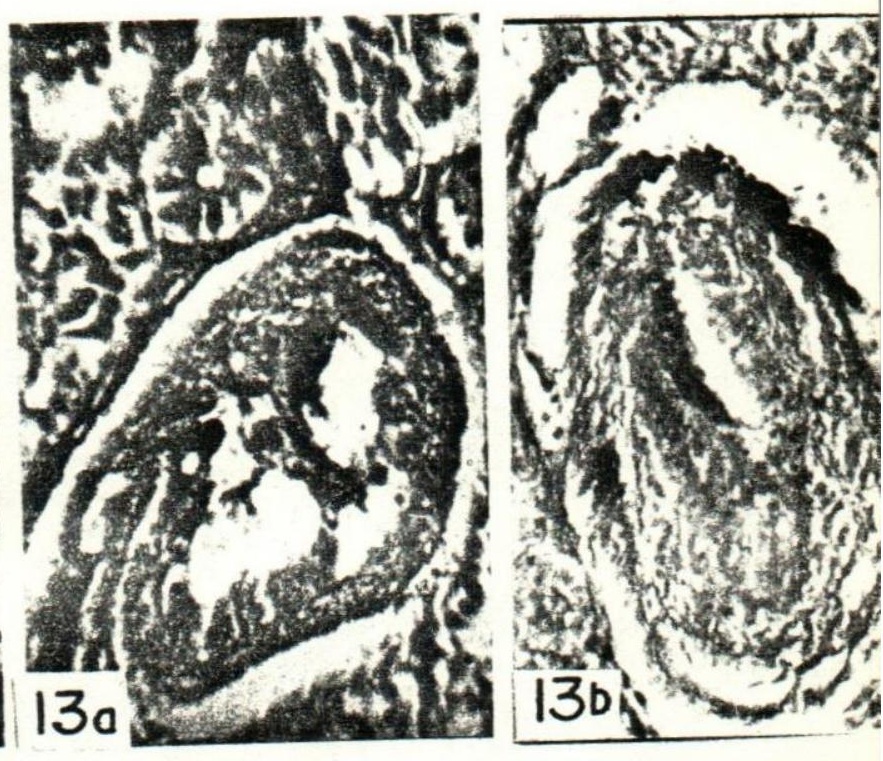

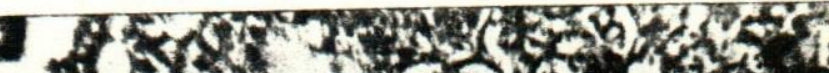

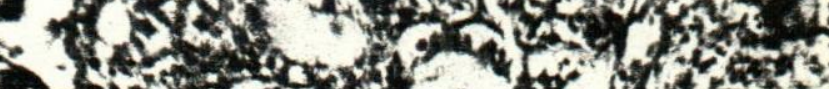
- $75,40,1 / 2$

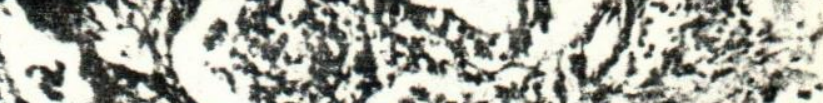

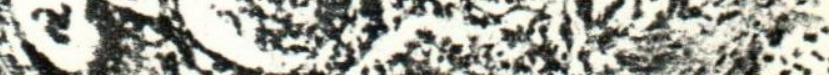

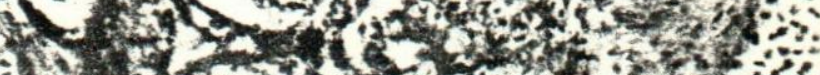

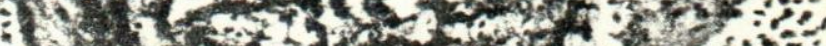

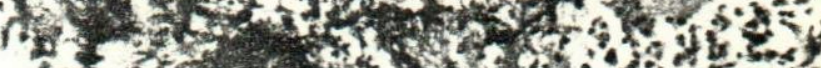
2.

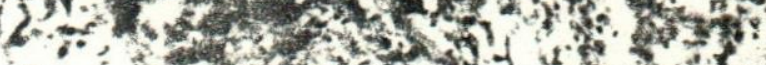

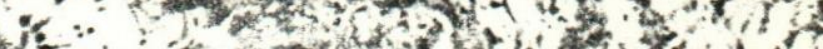

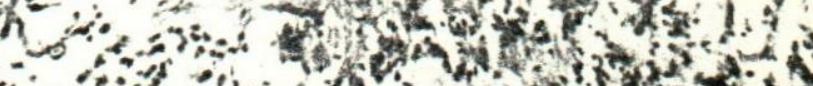

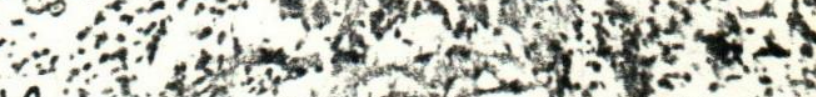
14 indity

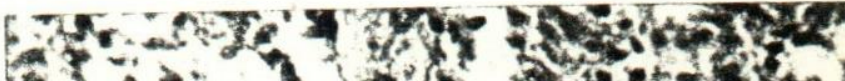
- 64.35

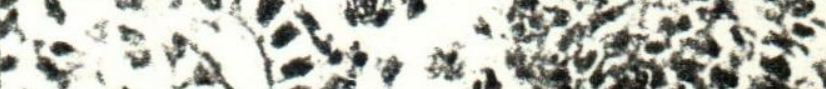

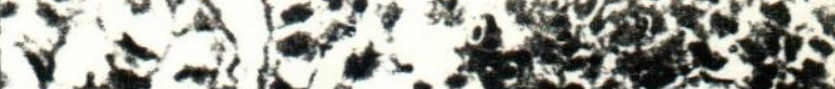
-7 $7-5,12$

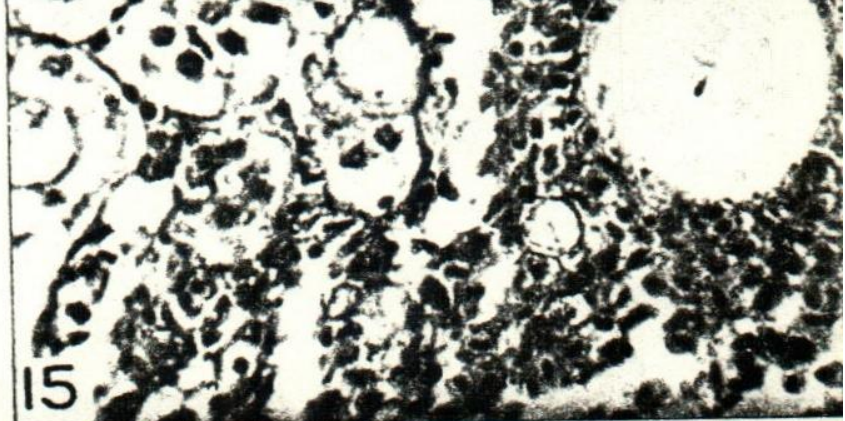



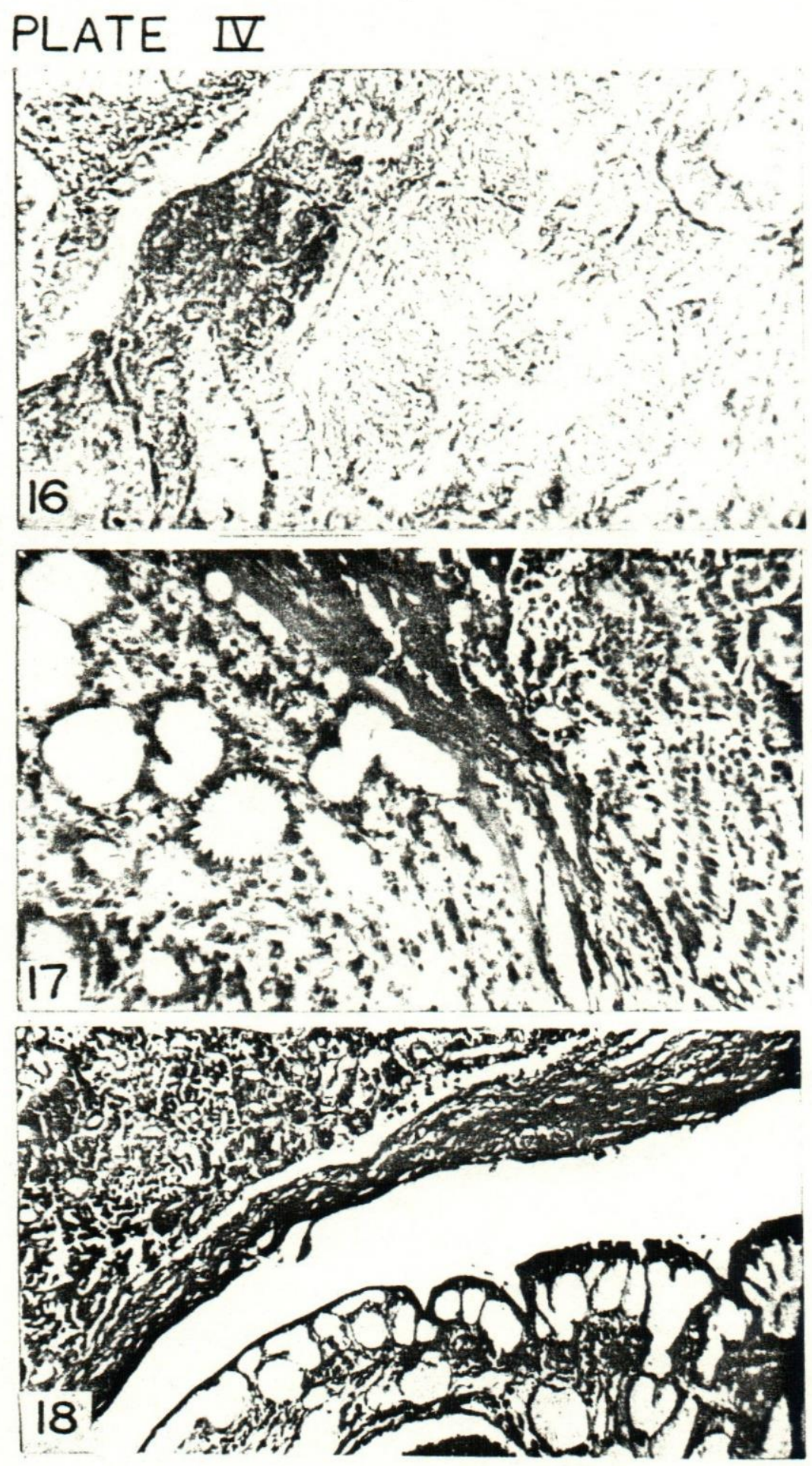